\title{
Outbreak of Clostridium perfringens type D enterotoxemia in sheep
}

\section{Surto de enterotoxemia por Clostridium perfringens tipo D em ovinos}

\author{
Felipe Masiero Salvarani ${ }^{1 *}$; Mayane Faccin²; Nayra Fernanda de Queiroz Ramos \\ Freitas $^{3}$; Mônica Regina de Matos²; Edismair Carvalho Garcia'; \\ Geane Maciel Pagliosa ${ }^{5}$; José Diomedes Barbosa ${ }^{1}$; Francisco Carlos Faria Lobato ${ }^{6}$; \\ Aline de Marco Viott ${ }^{5}$
}

\begin{abstract}
This work describes the first Brazilian laboratory-confirmed outbreak of enterotoxemia caused by Clostridium perfringens type D in sheep, which occurred in the state of Paraná. We address the epidemiological aspects involved, the diagnostic modalities employed, and the clinical signs and pathological findings observed. Eight healthy pregnant female sheep with no history of vaccination for clostridiosis presented with a history of abrupt feeding changes and neurological manifestations that quickly evolved to illness, coma and death. Four other females with clinical neurological signs were referred to the Veterinary Hospital of the Universidade Federal do Paraná, Palotina Sector. These animals presented with lethargy, motor incoordination, opisthotonus, pedal movements, muscle tremors, spastic paralysis, bruxism, mandibular trismus, sialorrhea, hyperexcitability and the inability to stand. They were examined and euthanized due to the seriousness of the clinical picture with an unfavorable prognosis. We performed gross anatomical and microscopic analyses of the organs and intestinal contents. We also performed bacterial isolation with molecular typing. From the intestinal contents, we detected toxins by means of the seroneutralization technique in mice. At necropsy, we noted pulmonary edema (2/4), necrotizing enteritis (4/4) and hyperemia of the leptomeninges (1/4). Microscopically, we observed lymphohistiocytic interstitial pneumonia, necrotic enteritis associated with the presence of rods, and nephrosis with interstitial lymphohistiocytic nephritis. No significant brain lesions were observed. Using serum neutralization, we identified epsilon toxin in the intestinal contents of all four animals. C. perfringens type D was identified. Based on the history, clinical signs, postmortem findings, and laboratory confirmation of the presence of epsilon toxin, we concluded that $C$. perfringens type $\mathrm{D}$ enterotoxemia caused this outbreak of sheep deaths.
\end{abstract}

Key words: Clostridiosis. Epsilon toxin. Neurological signs. Outbreak diagnosed. Small ruminant.

\section{Resumo}

Este trabalho descreve o primeiro surto brasileiro com confirmação laboratorial de enterotoxemia em ovinos por Clostridium perfringens tipo D, ocorrido no estado do Paraná, abordando os aspectos

1 Profs. Drs., Universidade Federal do Pará, UFPA, Castanhal, PA, Brasil. E-mail: felipems@ufpa.br; diomedes@ufpa.br

2 Discentes, Universidade Federal do Paraná, UFPR, Palotina, PR, Brasil. E-mail: mayanefaccin@hotmail.com; monicareginadematos@gmail.com

3 Discente, UFPA, Castanhal, PA, Brasil; E-mail: nayraffreitas@gmail.com

4 Pesquisador, Universidade Federal de Goiás, UFG, Jataí, GO, Brasil. E-mail: edismair@ufg.br

5 Prof ${ }^{\text {as }}$ Dras, UFPR, Palotina, PR, Brasil. E-mail: geaneplagiosa@gmail.com; viott@ufpr.br

6 Prof. Dr., Universidade Federal de Minas Gerais, UFMG, Belo Horizonte, MG, Brasil. E-mail: flobato@vet.ufmg.br

* Author for correspondence 
epidemiológicos envolvidos, sinais clínicos observados, achados patológicos e diagnóstico empregado. Oito fêmeas ovina, gestantes, em bom estado corporal e com histórico de mudanças bruscas na alimentação, sem histórico de vacinação para clostridioses, apresentaram manifestações clínicas neurológicas que logo evoluíram para decúbito, coma e morte. Outras quatro fêmeas apresentaram os sinais clínicos neurológicos e foram encaminhadas ao Hospital Veterinário da Universidade Federal do Paraná, setor Palotina. Os animais foram examinados e submetidos à eutanásia devido à gravidade do quadro clínico e prognóstico desfavorável. Destes quatro animais foram coletados fragmentos de órgãos e do conteúdo intestinal. Foi realizada análise macroscópica e microscópica dos órgãos, bem como isolamento bacteriano, tipificação molecular do agente e a deteç̧ão das toxinas por meio da técnica de soroneutralização em camundongos a partir do conteúdo intestinal. Os quatro ovinos examinados apresentaram letargia, incoordenação motora, opistótono, movimentos de pedalagem, tremores musculares, paralisia espástica, bruxismo, trismo mandibular, sialorréia, hiperexcitabilidade e decúbito. $\mathrm{Na}$ necropsia, constatou-se edema pulmonar (2/4), enterite necrohemorrágica (4/4) e hiperemia de leptomeninges (1/4). Microscopicamente havia pneumonia intersticial linfohistiocitária, enterite necrótica associada com a presença de bastonetes e nefrose com nefrite intersticial linfohistiocitária. Não foram observadas lesões encefálicas dignas de nota em função do quadro agudo da doença. Por meio da soroneutralização foi possível identificar a presença da toxina épsilon no conteúdo intestinal dos quatro animais em estudo. No isolamento e identificação microbiológica identificou-se C. perfringens tipo D. Diante do histórico, sinais clínicos, achados post-mpostmortem e a confirmação laboratorial da presença e identificação da toxina épsilon foi possível concluir o diagnóstico de enterotoxemia por $C$. perfringens tipo D como a causa do surto de mortes em ovinos no presente estudo.

Palavras-chave: Clostridioses. Toxina épsilon. Sinais neurológicos. Surto diagnosticado. Pequenos ruminantes.

\section{Introduction}

Enteric infections caused by Clostridium perfringens are generally referred to as enterotoxemia, a term associated with the presence of toxins produced in the gastrointestinal tract that are absorbed into the bloodstream and may cause local and systemic effects (POPOFF, 2011). $C$. perfringens is a gram-positive rod that is immobile and anaerobic. It is able to sporulate, a form of resistance that aids it persistence and survival, making $C$. perfringens difficult to eliminate (MOREIRA et al., 2016). The bacterium is classified into five toxigenic groups, namely, A, B, C, D and E, based on the production of four lethal toxins: alpha, beta, epsilon and iota toxins. Epsilon toxin, the main cause of $C$. perfringens type $\mathrm{D}$ enterotoxemia in small ruminants, alters the permeability of the vascular endothelium (LAYANA et al., 2006).

Factors that alter the intestinal environment, such as high levels of carbohydrates, high-protein diets and rich grasses, can stimulate the abundant growth of $C$. perfringens, accompanied by toxin production, leading to the clinical picture of enterotoxemia (SONGER, 1998). Because it is a potentially fatal disease that develops as an outbreak, enterotoxemia generates substantial economic losses worldwide (MOREIRA et al., 2016). Vaccination is the most efficient way to control clostridiosis (FERREIRA et al., 2016). In Brazil, there are few reports on the natural occurrence of enterotoxemia caused by $C$. perfringens type D in sheep (PIMENTEL et al., 2010; RISSI et al., 2010; LIRA et al., 2013).

To establish a presumptive diagnosis of $C$. perfringens enterotoxemia in small ruminants, it is useful to obtain a property history to document the clinical signs presented by the animals, as well as postmortem findings. However, the definitive diagnosis can only be made by means of laboratory confirmation through the detection of epsilon toxin (UZAL, 2004). The objective of this work was to describe the first Brazilian laboratoryconfirmed outbreak of enterotoxemia in sheep in the state of Paraná, addressing the epidemiological aspects involved, the clinical signs observed, the pathological findings, and the diagnostic methods. 


\section{Materials and Methods}

The outbreak

The disease outbreak occurred on a sheep farm located in the municipality of Maripá in the Western region of the state of Paraná, Brazil. The herd contained 23 animals of the Santa Inês breed. The history of the outbreak was provided by the owner. The herd was maintained in pens with access to water during the day and in a stone barn at night. Feeding was based on regular quality native pasture supplemented with bovine mineral salt mixed with common salt. The animals were regularly dewormed but were not vaccinated against clostridiosis.

Twelve nonvaccinated female sheep in the final stage of gestation became suddenly ill one day after the sheep herd had escaped and was found consuming chicken feed with $24 \%$ protein and $3.100 \mathrm{kCal} / \mathrm{kg}$ energy. Approximately $200 \mathrm{~kg}$ of chicken feed was housed in a facility that was accidentally left open and available to the animals for approximately 48 hours. The owner stated that the affected sheep had the best nutritional status compared with other animals on the farm. It was reported that eight females initially presented with acute signs of dizziness and difficulty with locomotion, which evolved into a prolonged inability to stand, coma, and consequent death. Eight animals died approximately six hours after the onset of clinical signs, and four were referred to the veterinary hospital of the Universidade Federal do Paraná, Palotina Sector for clinical evaluation.

\section{Necropsy and histopathology}

On the same day of the outbreak, four live pregnant ewes presenting with neurological manifestations were referred to the Veterinary Hospital of the Universidade Federal do Paraná, Palotina Sector. Due to the severity and acute progression of the clinical signs, the stricken animals were euthanized by intramuscular injection with 0.2 $\mathrm{mg} \mathrm{kg}^{-1}$ of xylazine and a slow intravenous infusion of $15 \mathrm{mg} \mathrm{kg}^{-1}$ thiopental with intrathecal lidocaine (NATALINI, 1993). After death, the animals were submitted to necropsy.

Fragments of the spleen, kidney, liver, lung, heart, and brain were collected and fixed in 10\% formaldehyde. The samples were processed at the UFPR for histopathological examination, embedded in paraffin, cut into $5 \mu \mathrm{m}$ thick sections and stained with hematoxylin-eosin (HE) (LUNA, 1968).

\section{Bacterial identification}

Samples of intestinal contents $(50 \mathrm{ml}$, one from each animal) were collected in sterile Falcon tubes for microbiological diagnosis. This refrigerated material was sent to the Anaerobic Laboratory of the Veterinary School of the Universidade Federal de Minas Gerais. Because of the clinical suspicion to enterotoxemia by $C$. perfringens type $\mathrm{D}$, smears were made directly from the intestinal contents and were submitted to Gram staining. Aliquots were inoculated in thioglycolate broth and blood agar with 5\% sheep blood and were incubated in an anaerobic atmosphere at $37^{\circ} \mathrm{C}$ for 24 hours. Gram staining was performed to determine the cellular morphology and tinctorial characteristics. From the blood agar plate, the colonies with double hemolysis were isolated and submitted to thermal extraction of genetic material for multiplex PCR. We screened specifically for alpha, beta, epsilon and iota toxinencoding genes (VIEIRA et al., 2008).

\section{Seroneutralization}

To confirm the presence of the toxin in the affected animals, each of the four intestinal contents were centrifuged under refrigeration at $4{ }^{\circ} \mathrm{C}$ at $10,000 \mathrm{x}$ $\mathrm{g}$ for 30 minutes. The supernatants were removed and filtered $(0.22 \mu \mathrm{m}$ pore $)$. Mice were divided into three groups: the first group was inoculated with only filtered intestinal content, the second group was inoculated with filtered content plus epsilon antitoxin mixture, and the third group was inoculated 
with only filtered content heated to $100{ }^{\circ} \mathrm{C}$. If the animals in the first group became ill and the animals in the second and third groups remained healthy, the sample was considered positive for the presence of epsilon clostridial toxin. Briefly, $1 \mathrm{~mL}$ of epsilon standard antitoxin was incubated at $37^{\circ} \mathrm{C}$ for 1 hour with $1 \mathrm{~mL}$ of each filtered intestinal content in a 1:1 dilution. Then, Swiss Webster mice weighing 18-22 g were intravenously inoculated with $0.2 \mathrm{~mL}$ of each sample and subsequently observed for 72 hours for survival, according to the methods of Tammemagy and Grant (1967) and Lobato et al. (2006).

\section{Results and Discussion}

Clinical signs

On clinical examination, the four sheep examined at the Veterinary Hospital presented lethargy, motor incoordination, opisthotonos, muscle tremors, spastic paralysis, pedal movements, bruxism, mandibular trismus, sialorrhea, hyperexcitability and the inability to stand.

\section{Pathological findings}

The locations of the lesions found in the carcasses during necropsy were similar among the four specimens, although they varied in intensity. Two animals had wet-looking, shiny, congested lungs, with a moderate amount of whitish frothy liquid exuding from the airways, suggesting pulmonary edema. One animal displayed a mild pericardial effusion (Figure 1). All animals displayed intestinal content hemorrhaging (Figure 2). Macroscopic lesions in the brain were observed in only one of the four cases, characterized by mild hyperemia of the cerebral cortex (Figure 3).

On microscopic evaluation, no significant histopathological changes were observed in the brain. In the mucosa of the small intestine, there was atrophy and flattening of the villi, with moderate diffuse necrosis of the intestinal epithelium and moderate diffuse lymphohistiocytic inflammatory infiltrates (Figure 4). There were numerous bacterial colonies of large agglomerated or loose bacilli in the intestinal lumen (Figure 5). The presence of diffuse and marked cytoplasmic vacuoles was prominent in the epithelium of the proximal convoluted tubules of the kidney. The interstitium contained moderately confluent multifocal lymphohistiocytic infiltrates. In the lungs, we observed multifocal areas of alveolar septal thickening with macrophage and lymphocyte infiltrates, with light focal fibroplasia. In the liver, centrilobular hepatocytes showed moderate cytoplasmic vacuoles with and without nucleus marginalization. In areas of the lung, liver, and kidney, there were multifocal areas of mononuclear infiltration, moderate consolidation of macrophages and few lymphocytes.

\section{Bacterial identification}

On bacteriological evaluation of the intestinal contents, we observed a large number of short, thick, nonsporulating gram-positive rods that were isolated or in chains. In the blood agar, we observed large, raised gray-white colonies with a double hemolysis halo. These findings were compatible with $C$. perfringens. Using multiplex PCR, the species was classified as $C$. perfringens type $\mathrm{D}$. 
Figure 1. Pericardial sac with moderate diffuse pericardial effusion in a Santa Inês, pregnant ewe. A moderate amount of transudate is observed within the pericardial sac resulting from vascular endothelial damage and resulting in increased permeability.

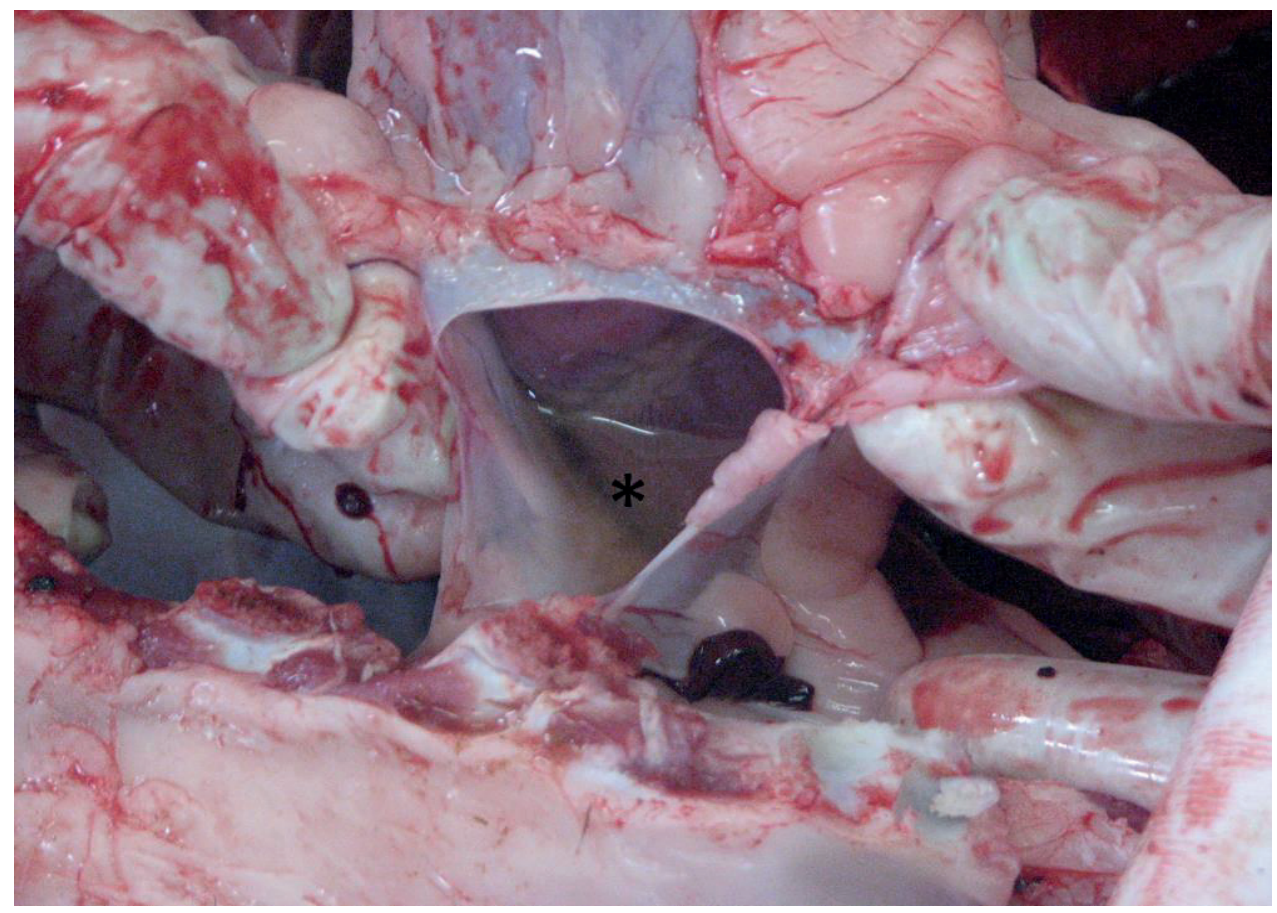

Figure 2. Small intestine with marked multifocal necrotizing enteritis in a Santa Inês, pregnant ewe. The mucosa of the small intestine is remarkably hyperemic, especially at the level of the jejunum and ileum, with intestinal content hemorrhaging.

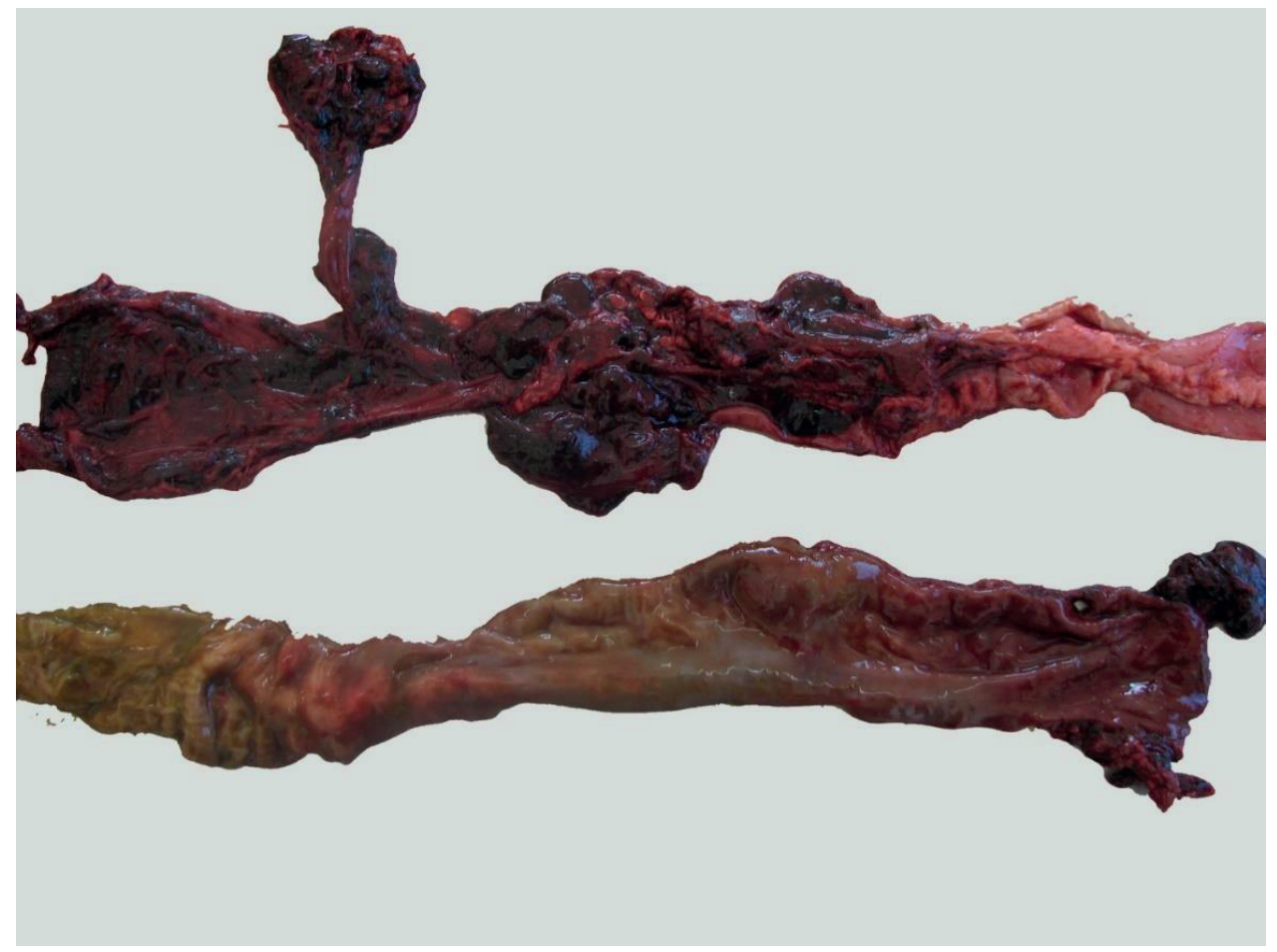


Figure 3. Leptomeninges with mild diffuse hyperemia in a Santa Inês, pregnant ewe. There is scant evidence of meningeal blood vessels due to the action of the epsilon toxin.

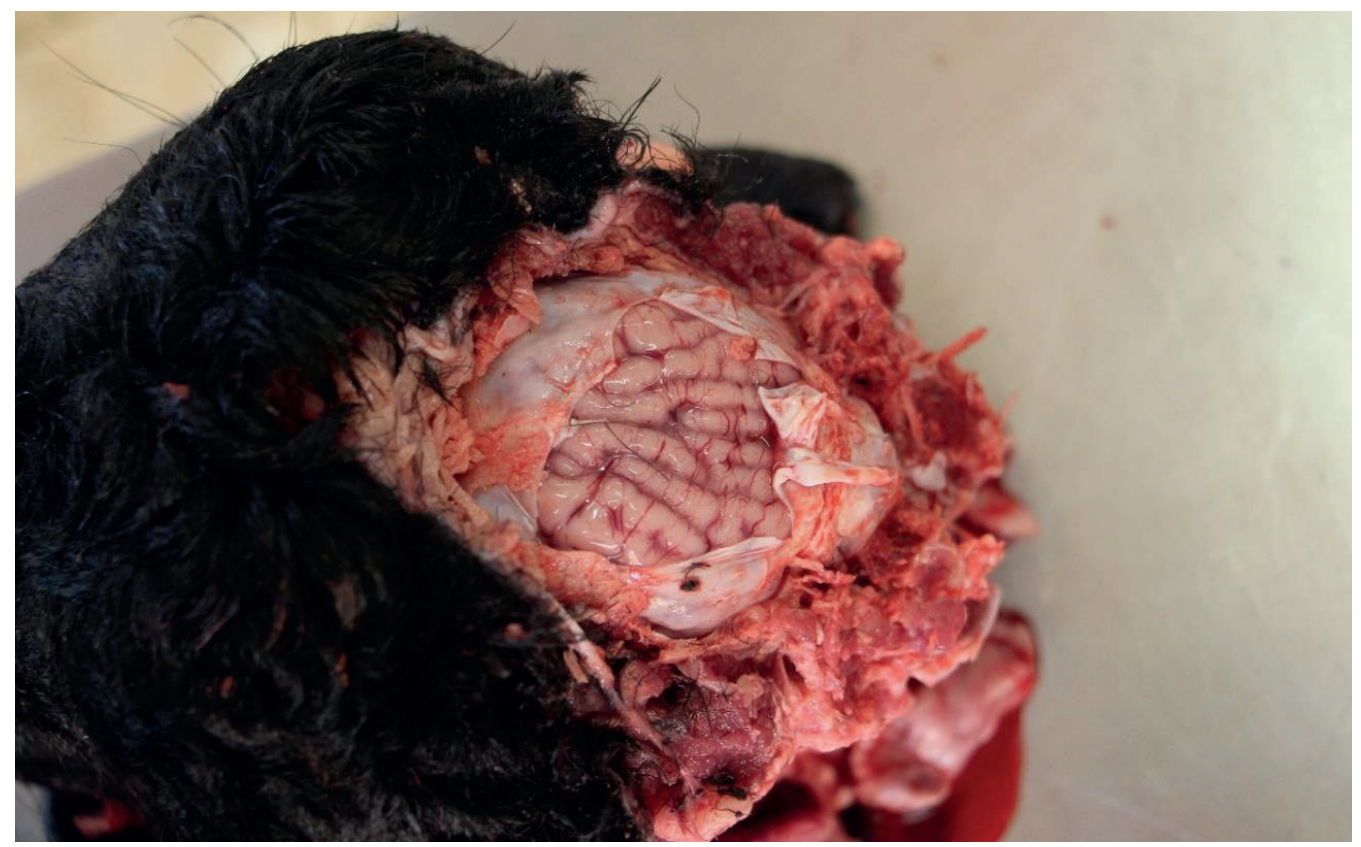

Figure 4. Jejunum with moderate diffuse necrotizing enteritis in a Santa Inês, pregnant ewe. Necrosis of the villus tips is observed (asterisk), along with hyperemia and hemorrhage and moderate lymphohistiocytic infiltrate (arrow) (HE, 40x).

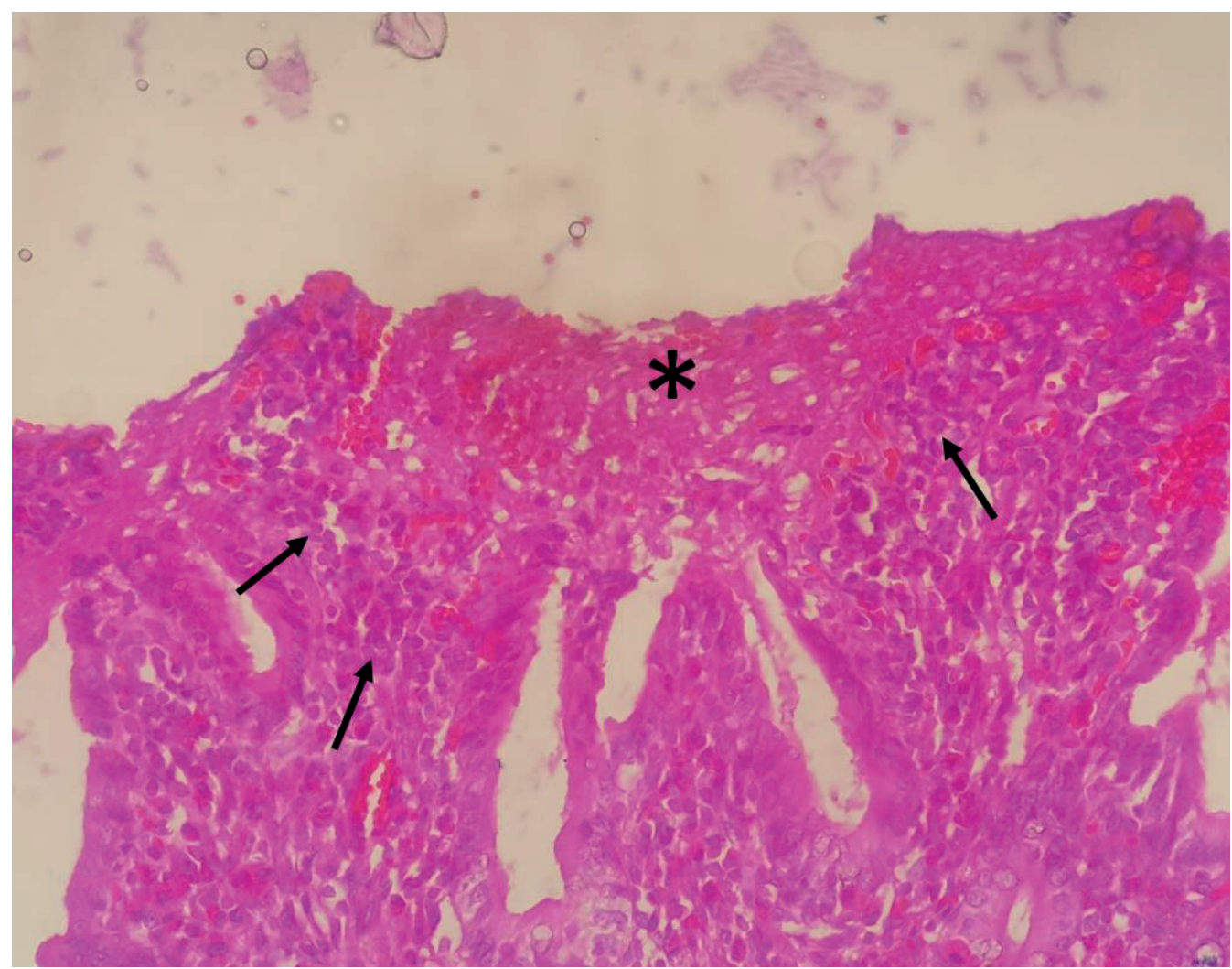


Figure 5. Jejunum with moderate diffuse necrotizing enteritis in a Santa Inês, pregnant ewe. In the lumen, there are numerous bacterial colonies of clustered or isolated loose bacilli, consistent with Clostridium perfringens (arrow) (HE, 100x).

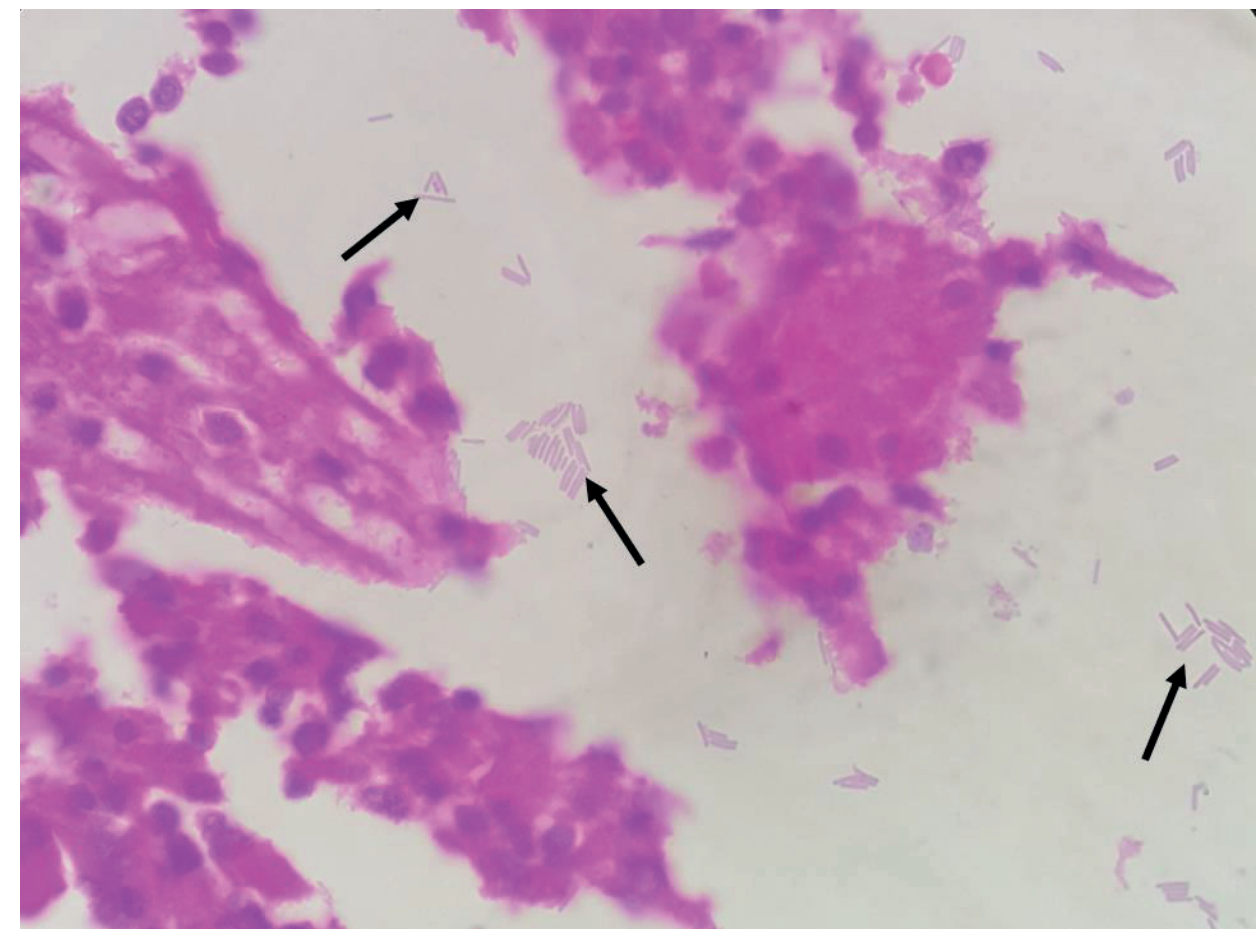

\section{Seroneutralization}

Mice inoculated with only the filtered intestinal contents died within 24 hours, whereas the mice that received filtrate plus epsilon antitoxin mixture and filtrate heated to $100^{\circ} \mathrm{C}$ survived. Epsilon toxin was also identified directly from the intestinal contents. Therefore, we were able to identify the toxin as epsilon in the intestinal contents of the four animals under study.

\section{Discussion}

C. perfringens is ubiquitous in the intestine of ruminants (FERREIRA et al., 2016). However, sudden diet changes may alter the microbiota and favor its overgrowth. In this outbreak, the affected animals ingested a high quantity of chicken feed without adaptation. The chicken rations are rich in soluble carbohydrates and proteins, possibly contributing to an imbalance in the intestinal microbiota of the sheep; additionally, chicken rations provide a source of nutrients for bacterial multiplication, creating conditions favorable for replication and toxin production (SONGER, 1998). The abrupt change in the animals' diet may have triggered these events. According to the report, all affected animals were pregnant females that had a better nutritional status than the other animals on the farm. In adults, the disease is more common in animals that eat larger quantities, present increased body scores and are being prepared for sale or slaughter. In general, the higher nutritional intake in animals occurs without prior adaptation to the diet (UZAL; KELLY, 1996). In pregnant ewes, there is a significant increase in energy demands during the last six weeks of gestation due to exponential fetal growth and the energetic requirements of milk production. As a result, the animal consumes more food and requires a high quality diet (CASTRO et al., 2013). These factors may explain why only the pregnant ewes were affected by the outbreak. 
Additionally, the affected herd had no history of vaccination against clostridiosis. According to Ferreira et al. (2016), vaccines against alpha, beta, and epsilon toxins are the best prophylactic measures to avoid enterotoxemia in farm animals.

The clinical manifestations observed in this outbreak were similar to those described by Uzal and Songer (2008). According to Popoff (2011), these signs develop as a result of the action of the epsilon toxin, which alters the integrity of endothelial cells in vessels of the central nervous system, leading to edema, degeneration, astrocyte rupture, and increased intracranial pressure. The toxin crosses the blood-brain barrier, stimulating the release of glutamate, an excitatory neurotransmitter, which in turn leads to the symptoms of excitation observed in cases of enterotoxemia (POPOFF, 2011).

The intestinal alteration in enterotoxemic sheep presents as mucosal hyperemia of the small intestine, which may contain a reddish-colored fluid, unlike goats that present more severe enteritis (UZAL; SONGER, 2008). With increased intestinal multiplication of $C$. perfringens and high epsilon toxin uptake, vascular permeability is altered, allowing not only the escape of fluid but also the escape of macromolecules, favoring the formation of edema, hemorrhage and congestion (POPOFF, 2011). Furthermore, all the pathological findings in the liver, lungs and kidneys can be explained by the action of the epsilon toxin, as described by Fernandez-Miyakawa and Uzal (2003).

Although cerebral microangiopathy is associated with $C$. perfringens type $\mathrm{D}$ infections in sheep (UZAL et al., 1997), this was not observed in the present study. According to Uzal and Songer (2008), the absence of macroscopic and microscopic changes in the central nervous system can occur in cases of acute or subacute enterotoxemia. This absence should not be considered sufficient to rule out the condition. In a study conducted by Facury Filho et al. (2009), in which bovines were experimentally inoculated with $C$. perfringens type D, only one animal survived eight days after the inoculation. At necropsy, they described a symmetrical focal region of encephalomalacia in the corpus striatum and perivascular proteinaceous edema in the brain, suggesting that the brain lesions require time to develop. In our study, the absence of microscopic brain lesions may have occurred due to the euthanasia procedure, as there was no time for the formation of macroscopic or microscopic lesions.

The isolation of $C$. perfringens from the intestinal contents of affected animals cannot be considered conclusive for the diagnosis of enterotoxemia, since the bacterium is part of the normal intestinal flora. Therefore, it is necessary to detect the epsilon toxin as well to confirm the occurrence of the disease (UZAL, 2004).

\section{Conclusion}

The detection of the epsilon toxin from $C$. perfringens type $\mathrm{D}$, the pathological lesions found, and the history and clinical signs observed allowed us to confirm enterotoxemia as the cause of the outbreak of sheep deaths. To our knowledge, this is the first report of a spontaneous outbreak of enterotoxemia in Brazil with laboratorial confirmation of the epsilon toxin by seroneutralization in mice. The animals affected were all pregnant, unvaccinated and had a history of abrupt changes in their diet. Prevention of future outbreaks may require the inclusion of vaccination for clostridiosis in sheep health maintenance protocols, as well as appropriate alimentary management to avoid abrupt changes in the feeding regimen.

\section{Acknowledgments}

The authors thank PROPESP-UFPA (PróReitora de Pesquisa e Pós Graduação da Universidade Federal do Pará), PPGSAAM-UFPA (Programa de Pós-Graduação em Saúde Animal na Amazônia da Universidade Federal do Pará), CNPq 
(Conselho Nacional de Desenvolvimento Científico e Tecnológico), FAPESPA (Fundação Amazônia de Amparo a Estudos e Pesquisas do Estado do Pará), INCT (Instituto Nacional de Ciência e Tecnologia) and the CAPES (Coordenação de Aperfeiçoamento de Pessoal de Nível Superior). We would also like to thank the workers from the Anaerobic Laboratory of the Veterinary School of the Universidade Federal de Minas Gerais for their contribution to this study.

\section{References}

CASTRO, F. A. B.; RIBEIRO, E. L. A.; MIZUBUTI, I. Y.; SILVA, L. D. F.; BARBOSA, M. A. A. F.; MARSON, B.; GRANDIS, F. A.; FERNANDES JÚNIOR, F.; PEREIRA, E. S. Energia dietética ao final da gestação e durante a lactação e desempenho de ovinos Santa Inês em sistema de acasalamento acelerado. Semina: Ciências Agrárias, Londrina, v. 34, n. 6, p. 4187-4202, 2013. DOI: 10.5433/1679-0359.2013v34n6Supl2p4187

FERNANDEZ-MIYAKAWA, M. E.; UZAL, F. A. The early effects of Clostridium perfringens type D epsilon toxin in ligated intestinal loops of goats and sheep. Veterinary Research Communications, Amsterdam, v. 27, n. 3, p. 231-241, 2003. DOI: 10.1023/A:1023348708599

FERREIRA, M. R. A.; MOREIRA, G. M. S. G.; CUNHA, C. E.; MENDONÇA, M.; SALVARANI, F. M.; MOREIRA, A.; CONCEIÇÃ̃O, F. R. Recombinant alpha, beta, and epsilon toxins of Clostridium perfringens: production strategies and applications as veterinary vacines. Toxins, Basileia, v. 8, n. 11, p. 340-364, 2016. DOI: $10.3390 /$ toxins 8110340

FILHO, E. J. F.; CARVALHO, A. U.; ASSIS, R. A.; LOBATO, F. F.; RACHID, M. A.; CARVALHO, A. A.; FERREIRA, P. M.; NASCIMENTO, R. A.; FERNANDES, A. A.; VIDAL, J. E.; UZAL, F. A. Clinicopathologic features of experimental Clostridium perfringens type D enterotoxemia in cattle. Veterinary Pathology, Thousand Oaks, v. 46, n. 6, p. 1213-1220, 2009. DOI: 10.1354/vp.08-VP-0304-U-FL

LAYANA, J. E.; FERNANDEZ-MIYAKAWA, M. E.; UZAL, F. A. Evaluation of different fluids for detection of Clostridium perfringens type D epsilon toxin in sheep with experimental enterotoxemia. Anaerobe, Londres, v. 12, n. 4, p. 204-206, 2006. DOI: 10.1016/j. anaerobe.2006.05.001

LIRA, M. A. A.; SIMÕES, S. V. D.; RIET-CORREA, F.; PESSOA, C. M. R.; DANTAS, A. F. M.; MIRANDA NETO, E. G. Doenças do sistema digestório de caprinos e ovinos no semiárido do Brasil. Pesquisa Veterinária Brasileira, Rio de Janeiro, v. 33, n. 2, p. 193-198, 2013. DOI: 10.1590/S0100-736X2013000200010.

LOBATO, F. C. F.; ASSIS, R. A.; ABREU, V. L. V.; SOUZA, J. R. M. F.; LIMA, C. G. R. D.; SALVARANI, F. M. Enterotoxemia em bovino. Arquivo Brasileiro de Medicina Veterinária e Zootecnia, Belo Horizonte, v. 58 , n. 5 , p. $952-954,2006$. DOI: $10.1590 / \mathrm{S} 0102-$ 09352006000500037

LUNA, L. G. Manual of histologic staining methods of the Armed Forces Institute of Pathology. $3^{\text {th }}$ ed. Nova York: Blakiston Division, Mcgraw-hill, 1968. 258 p.

MOREIRA, G. M. S. G.; SALVARANI, F. M.; CUNHA, C. E.; MENDONÇA, M.; MOREIRA, A.; GONÇALVES, L. A.; PIRES, P. S.; LOBATO, F. C. F.; CONCEIÇÃO, F. R. Immunogenicity of a trivalent recombinant vaccine against Clostridium perfringens alpha, beta, and epsilon toxins in farm ruminants. Scientific Reports, Londres, v. 6, p. $22816-22825$, 2016. DOI: $10.1038 /$ srep22816

NATALINI, C. C. General anestesia in sheep for experimental surgeries. Ciência Rural, Santa Maria, v. 23 , n. 1 , p. $117-122$, 1993. DOI: 0.1590/S010384781993000100022

PIMENTEL, L. A.; OLIVEIRA, D. M.; GALIZA, G. J. N.; DANTAS, A. F. M.; UZAL, F.; RIET-CORREA, F. Focal symmetrical encephalomalacia in sheep. Pesquisa Veterinária Brasileira, Rio de Janeiro, v. 30, n. 5, p. 423427, 2010. DOI: 10.1590/S0100-736X2010000500009

POPOFF, M. R. Epsilon toxin: a fascinating pore-forming toxin. FEBS Journal, Oxford, v. 278, n. 23, p. 4602-4615, 2011. DOI: $10.1111 /$ j.1742-4658.2011.08145.x

RISSI, D. R.; PIEREZAN, F.; OLIVEIRA FILHO, J. C.; FIGHERA, R. A.; IRIGOYEN, L. F.; KOMMERS, G. D.; BARROS, C. S. L. Doenças de ovinos da região Central do Rio Grande do Sul: 361 casos. Pesquisa Veterinária Brasileira, Rio de Janeiro, v. 30, n. 1, p. 21-28, 2010. DOI: $10.1590 / \mathrm{S} 0100-736 \mathrm{X} 2010000100004$

SONGER, J. G. Clostridial diseases of small ruminants. Veterinary Research, London, v. 29, n. 3-4, p. 219-232, 1998.

TAMMEMAGI, L.; GRANT, K. M. Vaccination in the control of bovine botulism in Queensland. Australian Veterinary Journal, v.43, n. 9, p. 368-372, 1967.

UZAL, F. A. Diagnosis of Clostridium perfringens intestinal infections in sheep and goats. Anaerobe, Londres, v. 10, n. 2, p. 135-143, 2004. DOI: $10.1016 /$ j. anaerobe.2003.08.005

UZAL, F. A.; GLASTONBURY, J. R. W.; KELLY, W. R.; THOMAS, R. Caprine enterotoxaemia associated with 
cerebral microangiopathy. Veterinary Record, Londres, v. 141, n. 9, p. 224-226, 1997.

UZAL, F. A.; KELLY, W. R. Enterotoxaemia in goat: a review. Veterinary Research Communications, Amsterdam, v. 20, n. 6, p. 481-492, 1996.

UZAL, F. A.; SONGER, J. G. Diagnosis of Clostridium perfringens intestinal infections in sheep and goats.
Journal of Veterinary Diagnostic Investigation, Thousand Oaks, v. 20, n. 3, p. 253-265, 2008. DOI: $10.1177 / 104063870802000301$

VIEIRA, A. A. S.; GUEDES, R. M.; SALVARANI, F. M.; SILVA, R. O. S.; ASSIS, R. A.; LOBATO, F. C. F. Genotipagem de Clostridium perfringens isolados de leitões diarreicos. Arquivos do Instituto Biológico, São Paulo, v. 75, n. 4, p. 513-516, 2008. 